\title{
Analisis Standar Proses Pendidikan Sekolah Menengah Pertama Al-Azhar Syifa Budi Parahyangan
}

\author{
1)Deswita, 2)Erwin Firdaus, 3)Boy Arief Rochman, 4)Ujang Cepi Barlian, 5)Sofyan Sauri \\ 1)STKIP Kusuma Negara Jakarta \\ 2),4),5) Universitas Islam Nusantara Bandung \\ 3)STAI Al-Falah Cicalengka Bandung \\ E-mail: deswita@stkipkusumanegara.ac.id
}

\begin{abstract}
Article Info
Article History

Received: 2020-11-17

Revised: 2021-01-05

Published: 2021-01-13

Abstract

The implementation of the 8 (eight) National Education Standards in a school will be carried out well if there is harmonization and common views among stakeholders, namely: foundations, school principals, teachers, school committees, and the surrounding community. The research objective was to determine the analysis, problems and describe remedial solutions related to the analysis of Al Azhar Syifa Budi

Keywords:

Analysis;

Educational Process

Standards;

Junior high school. Parahyangan Junior High School Education Process Standards in West Bandung Regency. This study uses a qualitative approach and literature review analysis methods. The results of the study were in the form of a standard analysis of the education process based on the characteristics of planning, implementation, assessment, and evaluation of learning, as well as problems faced related to the report on the number of students in Dapodik, the not optimal ability of newly recruited teachers and optimization of learning SOPs. The steps that have been carried out at this school are to make a report in Dapodik uniting 4 (four) study groups into 3 (three) study groups. Induction program, in-house training, supervision and coaching programs. The stages that have been carried out in school are mapping, recovery, empowering, improvement, development and establishing. The learning program SOP is gradually being refined along with the implementation of the ISO $9001-2015$ Quality Management System.
\end{abstract}

\begin{tabular}{l}
\hline Artikel Info \\
\hline Sejarah Artikel \\
Diterima: $2020-11-17$ \\
Direvisi: 2021-01-05 \\
Dipublikasi: $2021-01-13$
\end{tabular}

Kata kunci: Analisis; Standar Proses pendidikan; Sekolah Menengah Pertama. \begin{abstract}
Abstrak
Penerapan 8 (delapan) Standar Nasional Pendidikan di suatu sekolah akan dapat dilaksanakan dengan baik apabila terdapat harmonisasi dan kesamaan pandangan di antara para stakeholders, yaitu: yayasan, kepala sekolah, guru, komite sekolah, serta masyarakat sekitar. Tujuan penelitian adalah untuk mengetahui analisis, permasalahan dan mendeskripsikan solusi perbaikan berkaitan dengan analisis Standar Proses Pendidikan Sekolah Menengah Pertama Al Azhar Syifa Budi Parahyangan di Kabupaten Bandung Barat. Penelitian ini menggunakan pendekatan kualitatif dan metode analisis kajian pustaka. Hasil penelitian berupa Analisis standar proses pendidikan berdasarkan karakteristik perencanaan, pelaksanaan, penilaian, dan evaluasi pembelajaran, adapaun masalah yang dihadapi berkaitan laporan jumlah siswa di Dapodik, belum optimalnya kemampuan guru yang baru direkrut dan optimalisasi SOP pembelajaran. Tahapan yang sudah dilakukan disekolah ini adalah membuat laporan dalam Dapodik menyatukan 4 (empat) rombongan belajar menjadi 3 (tiga) rombongan belajar. Adanya program Induksi, in house training, program supervisi dan coaching. Tahapan yang sudah dilakukan disekolah adalah melakukan Mapping, Recovery, Empowering, Improvement, Development dan Establish. SOP program pembelajaran secara bertahap disempurnakan seiring dengan implementasi Sistem Manajemen Mutu ISO $9001-2015$.
\end{abstract}

\section{PENDAHULUAN}

Berdasarkan Pancasila dan UUD Negara Republik Indonesia Tahun 1945 Pendidikan Nasional berfungsi mengembangkan kemampuan dan membentuk watak serta peradaban bangsa Indonesia yang bermartabat dalam rangka mencerdaskan kehidupan bangsa, bertujuan untuk mengembangkan potensi peserta didik agar menjadi manusia yang beriman dan bertakwa kepada Tuhan Yang Maha Esa, berakhlak mulia, sehat, berilmu, cakap, kreatif, mandiri, dan menjadi warga negara yang demokratis serta bertanggung jawab. Untuk mengemban fungsi tersebut pemerintah menyelenggarakan suatu sistem pendidikan nasional sebagaimana tercantum dalam 
UU Nomor 20 Tahun 2003 tentang Sistem Pendidikan Nasional (Sisdiknas).

Keharusan UU itu juga berimplikasi pada pemerintahan dan satuan-satuan pendidikan. Pemerintah berupaya menciptakan sistem pendidikan nasional yang berstandar serta mempersiapkan anggaran yang optimal, melalui APBN dan APBD. Sedangkan satuan-satuan pendidikan hendaknya mampu menyelenggarakan proses pendidikan dan pembelajaran dengan baik dan berstandar sebagaimana ketetapan Badan Standar Nasional Pendidikan (BSNP). Penerapan 8 (delapan) Standar Nasional Pendidikan di suatu pendidikan akan dapat dilaksanakan dengan baik apabila terdapat harmonisasi dan kesamaan pandangan di antara para stakeholders, seperti: yayasan, kepala sekolah, guru, komite sekolah, serta masyarakat sekitar. Artinya setiap stakeholders hendaknya memiliki visi,misi dan tujuan yang sama. Tentunya hal ini memerlukan sosialisasi, komitmen, konsistensi dan keterlibatan semua pihak.

Implementasi UU Nomor 20 Tahun 2003 tentang Sistem Pendidikan Nasional dijabarkan ke dalam sejumlah peraturan antara lain Peraturan Pemerintah Nomor 19 Tahun 2005 tentang Standar Nasional Pendidikan diperbaharui dengan peraturan pemerintah no. 32 tahun 2013. Dalam rangka melaksanakan peraturan tersebut pemerintah menetapkan Peraturan Menteri Pendidikan Nomor 22 tahun 2016 tentang standar proses pendidikan. Menurut PP no. 19 tahun 2005 tentang Standar Nasional Pendidikan sebagaimana telah diubah dengan Peraturan Pemerintah Nomor 32 Tahun 2013 tentang Perubahan atas Peraturan Pemerintah Nomor 19 Tahun 2005 tentang Standar Nasional Pendidikan. Disebutkan bahwa standar Proses adalah kriteria mengenai pelaksanaan pembelajaran pada satuan pendidikan untuk mencapai Standar Kompetensi Lulusan (SKL). Standar Proses dikembangkan mengacu pada Standar Kompetensi Lulusan dan Standar Isi. Standar proses pendidikan ini meliputi karakteristik pembelajaran, perencanaan pembelajaran, pelaksanaan pembelajaran, penilaian pembelajaran serta pengawasan pembelajaran. Dari pengertian tersebut ada beberapa hal yang perlu di garis bawahi. Pertama, SNP yang berarti standar ini berlaku untuk setiap lembaga pendidikan formal pada jenjang pendidikan tertentu dimanapun pendidikan itu berada secara nasional.Kedua, standar proses pendidikan berkaitan dengan pelaksanaan pembelajaran, yang berarti dalam standar proses pendidikan berisi tentang bagaimana seharusnya proses pembelajaran berlangsung. Ketiga, standar proses diarahkan untuk mencapai standar kompetensi lulusan (Wina Sanjaya,2001).

Langkah-langkah analisis standar proses berdasarkan Permendikbud no. 22 tahun 2016 mencakup perencanaan, pelaksanaan, penilaian dan pengawasan termasuk rencana tindak lanjut. Hal ini sejalan dengan yang disampaikan dalam Wikipedia yang menyebutkan bahwa PDCA, ( "Plan, Do, Check,
Act") (Rencanakan, Kerjakan, Cek, Tindak lanjuti), adalah suatu proses pemecahan masalah empat langkah iteratif yang umum digunakan dalam pengendalian kualitas. Metode ini dipopulerkan oleh W. Edwards Deming. Deming selalu merujuk metode ini sebagai siklus Shewhart. Teori belajar kontruktivisme dari John Dewey, Jean Piaget, Lev Vygotsky mengatakan peran guru adalah sebagai mediator, fasilitor, dan teman yang membuat situasi yang kondusif untuk terjadinya konstruksi pengetahuan pada diri peserta didik. untuk menyelesaikan setiap persoalan yang dihadapi. Latihan memecahkan masalah seringkali dilakukan melalui belajar kelompok dengan menganalisis masalah dalam kehidupan sehari-hari. Sedangkan peserta didik dituntut untuk belajar aktif dan dapat menemukan cara belajar yang sesuai bagi dirinya, belajar dibawah bimbingan, dan menjalani proses scaffolding.

Dalam meningkatkan proses pembelajaran dibutuhkan pelaksana pendidikan yg bermutu. Pelaksana tersebut adalah Kepala sekolah, guru dan tenaga kependidikan. Menurut Shielilo R Amihan, PhD., dalam an international conference on developing competencies of teachers indonesia (may 1-2, 4-5), mereka dituntut untuk menguasai keterampilan abad 21 yaitu 1) Fundational Literacies dimana peserta didik menerapkan keterampilan inti untuk tugas sehari-hari melalui kemampuan literasi, numerasi, ICT, literasi Science, financial literacy, cultural dan civic literacy. 2) Competencies, dimana peserta didik mendekati tantangan yang kompleks melalui critical thinking, creativity, communication, dan collaboration. 3) Character Qualities dimana peserta didik mendekati lingkungan mereka yang berubah meliputi curiocity, initiative, persistence/grit, adaptability, leadership dan social dan cultural awareness.

Berdasarkan Kompas.com. 02 Oktober 2018, hasil Uji Kompetensi Guru (UKG) tahun 2015, 2016 dan 2017 secara nasional masih dibawah 70 dari nilai maksimal 100. UKG dijalankan berdasarkan UU No. 14 Tahun 2005 tentang Guru dan Dosen dan menjadi bagian dari sertifikasi kemampuan guru. Selain sebagai bagian dari upaya peningkatan mutu. Capaian tiga tahun terakhir sejak 2015 dalam catatan Kemendikbud, peningkatan nilai secara signifikan terjadi pada 2016. Namun angka rata-ratanya hingga 2017 masih di bawah 70, untuk semua jenjang pendidikan dasar dan menengah. Pendidikan merupakan modal dasar pembangunan bangsa dan negara. Kemajuan suatu bangsa salah satunya ditentukan oleh mutu pendidikannya, sedangkan salah satu faktor penentu mutu pendidikannya adalah guru. (Waudin, Sofyan Sauri, 2019). Bahwa pelaksana pembelajaran yg bermutu merupakan hasil dari proses rekrutmen SDM yang unggul dalam memenuhi standar proses pendidikan.SDM yang unggul harus memenuhi criteria, yaitu mampu : Mengidentifikasi kriteria peserta didik, Mengidentifikasi gaya belajar peserta didik; Mengajar dalam suasana yang 
menyenangkan, Merancang mengajarkan yang memberikan tantangan, Mengajarkan kemampuan mengajar, Untuk mengajarkan kemandirian, membangun dan merangsang kemampuan berpikir pada anak , Bertanya untuk membangun logika pada anak, Menumbuhkan rasa ingin tahu pada anak, Merancang mengajarkan pembelajaran yang aman, Memotivasi untuk belajar, , mengajarkan memaknai, Mengajarkan kepribadian pada anak, Memenej kelas virtual dengan baik, Manajemen diri, Punya tanggung jawab terhadap tugas dan Memahami Etika dan hukum ITE dan IT software pembelajaran digital.

Persyaratan Pelaksanaan Proses Pembelajaran di SMP meliputi alokasi waktu 40 menit, rombongan belajar maksimal 32 peserta didik, buku teks yang disesuaikan dengan peserta didik serta pengelolaan kelas dan laboratorium yang terdiri dari :Guru wajib menjadi teladan yang baik bagi peserta didik dalam menghayati dan mengamalkan ajaran agama yang dianutnya serta mewujudkan kerukunan dalam kehidupan bersama,Guru wajib menjadi teladan bagi peserta didik dalam menghayati dan mengamalkan perilaku jujur, disiplin, tanggung jawab, peduli (gotong royong, kerja sama, toleran, damai), santun, responsif dan proaktif dan menunjukkan sikap sebagai bagian dari solusi atas berbagai permasalahan dalam berinteraksi secara efektif dengan lingkungan sosial dan alam serta dalam menempatkan diri sebagai cerminan bangsa dalam pergaulan dunia, Guru menyesuaikan pengaturan tempat duduk peserta didik dan sumber daya lain sesuai dengan tujuan dan karakteristik proses pembelajaran,Volume dan intonasi suara guru dalam proses pembelajaran harus dapat didengar dengan baik oleh peserta didik,Guru wajib menggunakan kata-kata santun, lugas dan mudah dimengerti oleh peserta didik,Guru menyesuaikan materi pelajaran dengan kecepatan dan kemampuan belajar peserta didik, Guru menciptakan ketertiban, kedisiplinan, kenyamanan, dan keselamatan dalam menyelenggarakan proses pembelajaran,, Guru memberikan penguatan dan umpan balik, terhadap respons dan hasil belajar peserta didik selama proses pembelajaran berlangsung, Guru mendorong dan menghargai peserta didik untuk bertanya dan mengemukakan pendapat, Guru berpakaian sopan, bersih, dan rapi, Pada tiap awal semester, guru menjelaskan kepada peserta didik silabus mata pelajaran;Guru memulai dan mengakhiri proses pembelajaran sesuai dengan waktu yang dijadwalkan.

Penilaian proses pembelajaran menggunakan pendekatan penilaian otentik (authentic assesment) yang menilai kesiapan peserta didik, proses, dan hasil belajar secara utuh. Keterpaduan penilaian ketiga komponen tersebut akan menggambarkan kapasitas, gaya, dan perolehan belajar peserta didik yang mampu menghasilkan dampak instruksional (instructional effect) pada aspek pengetahuan dan dampak pengiring (nurturant effect) pada aspek sikap.
Pengawasan proses pembelajaran dilakukan melalui kegiatan pemantauan, supervisi, evaluasi, pelaporan, serta tindak lanjut secara berkala dan berkelanjutan. Pengawasan proses pembelajaran dilakukan oleh kepala satuan pendidikan dan pengawas. Prinsip Pengawasan Pengawasan dilakukan dengan prinsip objektif dan transparan guna peningkatan mutu secara berkelanjutan. .

\section{METODE PENELITIAN}

Penelitian ini menggunakan pendekatan kualitatif dan metode analisis kajian pustaka. Peneliti mengambil data dengan teknik mencari referensi dari berbagai sumber pustaka, terutama mengambil data dari sumber primer dan sumber sekunder. Sumber primer yakni sumber data utama yang dicari, adapun sumber sekunder merupakan data pendukung. Sumber primer terdiri dari Undang-Undang Nomor 20 tahun 2003 tentang Sistem Pendidikan Nasional, Peraturan Pemerintah Nomor 19 tahun 2005 tentang Standar Nasional Pendidikan, dan Peraturan Menteri Pendidikan dan Kebudayaan Republik Indonesia Nomor 22 Tahun 2016 Tentang Standar Proses Pendidikan Dasar dan Menengah. Adapun sumber sekunder terdiri dari buku, jurnal, hasil seminar dan diskusi dengan ahli yang relevan dengan tema penelitian. Setelah data terkumpul peneliti melakukan analisis dengan analisis deskriptif dan interpretasi data, kemudian peneliti memberikan penjelasan secukupnya.

\section{HASIL DAN PEMBAHASAN}

SMP Al Azhar Syifa Budi Parahyangan (ASBP) Bandung Barat, memiliki visi "The Good Academic and Tahfizh School for Creating Good Academic and Tahfizh Learners". dan Misi "Producing good academic learning by good academic teaching, Presenting good human resource inspiring others with Alquran". Mengacu pada visi dan misi sekolah, serta tujuan umum pendidikan dasar, dalam mengembangkan pendidikan, SMP ASBP melaksanakan pendekatan "pembelajaran aktif" pada semua mata pelajaran.

Mengembangkan berbagai kegiatan dalam proses belajar di kelas berbasis pendidikan budaya dan karakter bangsa dan kewirausahaan; terpenuhinya perangkat pembelajaran untuk semua mata pelajaran dengan mempertimbangkan pengembangan nilai religius dan budi pekerti luhur. Memanfaatkan dan memelihara fasilitas untuk sebesar-besarnya dalam proses pembelajaran dan menciptakan guru yang kompeten dan profesional. Terwujudnya budaya sekolah yang kondusif untuk mencapai tujuan pendidikan antara lain: gemar membaca, kerjasama, saling menghargai, displin , jujur, kerja keras, kreatif dan inovatif. Terwujudnya peningkatan Prestasi dibidang Akademik dan non-Akademik Terwujudnya suasana pembelajaran yang menantang, menyenangkan, komunikatif, tanpa takut salah, dan demokratis. Terwujudnya efisiensi waktu belajar, optimalisasi penggunaan sumber belajar dilingkungan 
untuk menghasilkan karya dan prestasi yang maksimal. Terwujudnya lingkungan sekolah yang memiliki kepedulian sosial dan lingkungan, cinta damai, cinta tanah air, semangat kebangsaan, serta hidup demokratis yang menjadi bagian dari pendidikan budaya dan karakter bangsa dan kewirausahaan. Menjalin kerja sama lembaga pendidikan dengan media dalam mempublikasikan program sekolah. Menumbuh kembangkan peran serta masyarakat dalam bidang pendidikan Mewadahi serta memfasilitasi individu maupun masyarakat pemerhati atau pakar pendidikan yang peduli tehadap peningkatan kualitas pendidikan secara profesional yang selaras dengan kebutuhan pengembangan pendidikan. Selalu mengkaji dan memecahkan permasalahan pendidikan dalam rangka meningkatkan kualitas pendidikan termasuk kurikulum baik lokal maupun nasional. Menciptakan SMP Al Azhar Syifa Budi Parahyangan sebagai sekolah yang sehat dan unggul. Mengembangkan inovasi pendidikan dan Meningkatkan kesejahteraan pegawai atau guru. Meningkatkan mutu pelayanan di bidang pendidikan serta Memberi kesempatan peserta didik untuk:belajar untuk beriman dan bertakwa kepada Tuhan Yang Maha Esa,belajar untuk memahami dan menghayati,belajar untuk mampu melaksanakan dan berbuat secara efektif,belajar untuk hidup bersama dan berguna untuk orang lain, danbelajar untuk membangun dan menemukan jati diri melalui proses belajar yang aktif, kreatif, efektif dan menyenangkan.

Saat ini SMP Al-Azhar Syifa Budi parahyangan memiliki kurang lebih 265 siswa dengan 11 rombel. Adapun tenaga pendidik berjumlah 21 0rang dan tenaga kependidikan 9 orang. Untuk mencapai visi, sekolah mengadakan kegiatan ko kurikuler (Ikrar Tiga bahasa, kepemimpinan islami, tahsin dan tahfidz $\mathrm{Al}$ Qur'an, fieldtrip dalam negeri dan luar negeri, perkemahan terpadu, pramuka/lifeskill, penyaluran qurban, organisasi siswa dan bakti sosial.) dan ekstra kurikuler (teater, panahan, menari, melukis, web dan animasi, gitar, robotik, merpati putih, berkuda, futsal, basket dan volley ball.) Sedangkan Program Unggulan Sekolah yaitu Program Bilingual, Spiritualisasi dan Saintifikasi Pendidikan, Tahsin dan Tahfidz Al Qur'an, Fieldtrip dalam Negeri dan Luar Negeri dan Pembelajaran berbasis teknologi

Sesuai dengan Standar Kompetensi Lulusan, sasaran pembelajaran mencakup pengembangan ranah sikap, pengetahuan, dan keterampilan yang dielaborasi untuk setiap satuan pendidikan. Untuk mendorong kemampuan peserta didik untuk menghasilkan karya kontekstual, baik individual maupun kelompok maka sangat disarankan menggunakan pendekatan pembelajaran yang menghasilkan karya berbasis pemecahan masalah (project based learning). PJBL ini juga diterapkan dalam Pembelajaran Jarak Jauh (PJJ) saat ini. Perencanaan pembelajaran dirancang dalam bentuk Silabus dan Rencana Pelaksanaan Pembelajaran (RPP) yang mengacu pada Standar Isi. Perencanaan pembelajaran meliputi penyusunan rencana pelaksanaan pembelajaran dan penyiapan media dan sumber belajar, perangkat penilaian pembelajaran, dan skenario pembelajaran.

Berdasarkan hasil observasi dan studi dokumentasi, penyusunan Silabus sudah memuat: Identitas mata pelajaran; Identitas sekolah meliputi nama satuan pendidikan dan kelas;Kompetensi Inti (KI); kompetensi Dasar (KD), materi pokok, memuat fakta, konsep, prinsip, dan prosedur yang relevan, dan ditulis dalam bentuk butir-butir sesuai dengan rumusan indikator pencapaian kompetensi; pembelajaran; penilaian; Alokasi waktu sesuai dengan jumlah jam pelajaran dalam struktur kurikulum untuk satu semester atau satu tahun; dan Sumber belajar.

Untuk sekolah ini sudah memasukkan pendidikan karakter (Religius, Jujur, Toleransi, Disiplin, Kerja Keras, Kreatif, Mandiri, Demokratis, Rasa Ingin Tahu, semangat Kebangsaan,Cinta Tanah Air, Menghargai Prestasi, komunikatif, Cinta Damai, Gemar Membaca, Peduli Lingkungan, Peduli Sosial dan Tanggung Jawab) dan spiritualisasi pendidikan ke dalam silabus, Komponen RPP sekolah sudah terdiri dari : identitas sekolah; identitas mata pelajaran atau tema/subtema; kelas/semester; materi pokok; alokasi waktu ; tujuan pembelajaran; kompetensi dasar dan indikator pencapaian kompetensi; materi pembelajaran; metode pembelajaran,;media pembelajaran,sumber belajar, (berupa buku paket, E-book, video pembelajaran, Learning Management System, dan alam sekitar); langkah-langkah pembelajaran; dan penilaian hasil pembelajaran.

Untuk sekolah memasukkan juga nilai-nilai karakter dan spiritualisasi pendidikan ke dalam Rencana Pelaksanaan Pembelajaran (RPP). Media pembelajaran menggunakan Smart TV yang bisa terhubung ke internet, Tab, dan Laptop. Pembuatan RPP ini sudah mengacu kepada prinsip penyusunan RPP yakni meliputi : Perbedaan individual peserta, Partisipasi aktif peserta didik, Berpusat pada peserta didik,Pengembangan budaya membaca dan menulis, Pemberian umpan balik dan tindak lanjut RPP, Penekanan pada keterkaitan dan keterpaduan antara KD, materi pembelajaran, kegiatan pembelajaran, indicator pencapaian kompetensi, penilaian, dan sumber belajar dalam satu keutuhan pengalaman belajar, Mengakomodasi pembelajaran tematikterpadu, keterpaduan lintas mata pelajaran, lintas aspek belajar, dan keragaman budaya, Penerapan teknologi informasi dan komunikasi secara terintegrasi, sistematis, dan efektif sesuai dengan situasi dan kondisi.

SMP Al Azhar Syifa Budi Parahyangan berusaha menggunakan prinsip mastery learning (ketuntasan belajar) walaupun sistem paket. Artinya setiap peserta didik harus mengikuti kegiatan kenaikan kelas bersama-sama, sedangkan untuk yang belum tuntas KKM harus mengikuti pembelajaran remidial, dan peserta didik yang sudah mencapai KKM mengikuti kegiatan pengayaan. Pengawasan proses pembelajaran dilakukan melalui kegiatan pemantauan, supervisi, evaluasi, pelaporan, serta 
tindak lanjut secara berkala dan berkelanjutan. Pengawasan proses pembelajaran dilakukan oleh kepala satuan pendidikan dan pengawas.

Berdasarkan hasil observasi yang dilakukan di lokasi penelitian, menunjukkan bahwa dalam proses pembelajaran mulai dari perencanaan, pelaksanaan, penilaian dan pengawasan sudah berjalan baik, sesuai dengan program yang sudah berjalan di sekolah. Hal ini tidak terlepas dari komitmen kepala Sekolah, guru dan Tenaga Administrasi Sekolah yang didukung oleh Dinas Pendidikan, Yayasan, dan komite sekolah. Adapun monitoring/pengawasan terhadap proses pembelajaranSekolah Menengah Pertama di Bandung Barat sebagai berikut: (1) Perlu juga dioptimalkan setiap anggota organisasi dalam melakukan pengawasan secara mandiri atas kerjanya, termasuk penerapan standar mutu pada pekerjaannya dan melakukan self assesment. Selama ini masih mengandalkan pengawasan hasil kerja dari pimpinan sekolah dan antar unit kerja masing-masing. (2) Evaluasi terhadap pembelajaran dilakukan secara terprogram berdasarkan kurikulum yang dikembangkan sesuai kebijakan yayasan. (3) Orang tua dapat memperoleh informasi kegiatan di sekolah dengan mudah dan transparan. Sekolah menyampaikan informasi kegiatan sekolah di awal tahun pelajaran dengan mengundang semua orang tua peserta didik, sekaligus dengan penjelasan dan pemberian buku kegiatan akademis dan kesiswaan selama satu tahun. Termasuk informasi lulusan yang memiliki standar untuk masuk ke sekolah bermutu pada tingkat yang lebih tinggi.

Adapun Hambatan pembelajaran sesuai standar proses pendidikan SMP Al Azhar Syifa Budi Parahyangan di Kabupaten Bandung Barat Berdasarkan wawancara berkaitan dengan hambatan dalam mengimplementasikan standar proses di sekolah, Kepala Sekolah mengatakan bahwa (1) Jumlah peserta didik per kelas paling banyak 28 dari maksimal 32 orang, namun pada kenyataannya pada saat pendataan di Dapodik terkait sertifikasi tetap mengharuskan jumlah siswa 32 orang. Kebijakan ini tidak sesuai dengan standar proses pendidikan ini. (2) Belum optimalnya tenaga pendidik dan kependidikan yang baru direkrut. Kriteria kemampuan guru di sekolah ini harus dapat mengidentifikasi kriteria peserta didik, mengidentifikasi gaya belajar peserta didik, mengajar dalam suasana yang menyenangkan, merancang mengajarkan yang memberikan tantangan, mengajarkan kemampuan mengajar,untuk mengajarkan kemandirian, membangun dan merangsang kemampuan berpikir pada anak ,bertanya untuk membangun logika pada anak,menumbuhkan rasa ingin tahu pada anak,merancang mengajarkan pembelajaran yang aman, memotivasi untuk belajar, mengajarkan memaknai, mengajarkan kepribadian pada anak, memenej kelas virtual dengan baik, manajemen diri,punya tanggung jawab terhadap tugas,memahami Etika dan hukum ITE dan IT software pembelajaran digital (3) SOP program pembelajaranbelum optimal.
Masih ditemukan perbedaan format dalam perencanaan dan pelaksanaan pembelajaran antara guru satu dengan lainnya.

Berdasarkan observasi terkait solusi dari hambatan-hanbatan tersebut adalah sebagai berikut: (1) Laporan dalam Dapodik menyatukan 4 (empat) rombongan belajar menjadi 3 (tiga) rombongan belajar (2) Adanya program Induksi, in house training dan pelatihan lainnya. Ada juga program supervisi dan coaching. Tahapan yang sudah dilakukan disekolah ini adalah melakukan Mapping, Recovery, Empowering, Improvement, Development dan Establish. (3) SOP program pembelajaran secara bertahap disempurnakan seiring dengan implementasi Sistem Manajemen Mutu ISO 9001 - 2015. Dalam SMM ISO secara sistematis dan terencana dibuatkan panduan mutu, target melalui sasaran mutu, identifikasi penanganan resiko (mitigasi), program kerja kemudian membuat SOP. Prinsip dari SMM ISO ini adalah tulis apa yang dikerjakan dan kerjakan apa yang ditulis. Tulis apa yang dikerjakan sebagai manifestasi dari evaluasi dan perbaikan. Kerjakan apa yang ditulis adalah dengan menjalankan perencanaan pembelajaran yang sudah dibuat.

Sekolah efektif atau sekolah bermutu adalah sekolah yang menetapkan Quality Assurance dan tercapai. Jadi bukan masalah banyak atau sedikit tetapi tercapai atau tidak tercapai. Disinilah salah satu peran penting analisisproses pembelajaran pendidikan. Dalam analisis proses pembelajaran agar supaya target dapat tercapai maka perlu dibuatkan target/sasaran mutu yang jelas dan terukur. Setelah itu dibuatkan program kerja, instruksi kerja dan Standar Operasi Prosedur untuk mencapai target yang akan dibuat. Hal lain yang tidak kalah berperan dalam pencapaian target selain sistem adalah adanya peran Kepemimpinan Kepala Sekolah, komitmen guru dan daya dukung sekolah. Dengan perencanaan, strategi, pelaksanaan, pengawasan dan evaluasi yang baik maka output dan outcome pembelajaran akan tercapai. Dan sekolah harus percaya diri menyampaikannya kepada orang tua dan masyrakat mengenai output dan outcome tersebut karena sistem dan sumber daya manusianya sudah dipersiapkan dengan baik.

Berdasarkan hasil observasi maka sekolah yang menjadi tempat penelitian sudah memiliki target/sasaran mutu, dokumen 1, buku penjelasan program pembelajaran yang disusun secara partisipatif melalui tim pengembang mutu sekolah dengan tujuan untuk memperbaiki dan meningkatkan mutu pembelajaran sekolah serta memonitor dan mengevaluasi capaian rencana tersebut yang telah dicapai. Buku program penjelasan pembelajaran tersebut diberikan dan disampaikan kepada orang tua peserta didik melalui pertemuan orang tua peserta didik di awal tahun pelajaran baru.

Sekolah ini telah melaksanakan proses pembelajaran dengan baik. Salah satu indikasinya adalah melalui ketercapaian dalam standar proses, bahkan sekolah memiliki kekhasan yang sudah 
tercapai. Hal ini dibuktikan bahwa sekolah tersebut telah mendapatkan penghargaan dalam pencapaian niala Ujian Nasional (UN) tertinggi di Bandung Barat. Sekolah ini pun disamping fokus terhadap pengembangan SDM, juga terhadap aspek keagamaan dan program multilingual (Arab, Inggris dan Indonesia). Baru-baru ini SMP ASBP telah mendapat Indeks Integritas pelaksanaan UN tertinggi tahun 2015 dari Menteri Pendidikan Republik Indonesia. Hal ini sebagai buah dari proses pembelajaran yang menekankan bukan hanya aspek pengetahuan dan keterampilan saja tetapi aspek spiritual dan Akhlak peserta didik.

Proses pembelajaran sudah sesuai dengan Standar Kompetensi Lulusan dimana sasaran pembelajaran mencakup pengembangan ranah sikap, pengetahuan, dan keterampilan yang dielaborasi untuk setiap satuan pendidikan. Ranah sikap diperkuat dengan penerapan iklim dan kultur yang Islami, pembiasaan yang baik dan program spiritualisasi pendidikan, Perencanaan dibuat dengan baik dan sesuai dengan standar proses pendidikan. Sudah semua guru mempunyai silabut dan membuat RPP diawal tahun ajaran baru. Pelaksanaan dan penilaian pembelajran pun sesuai standar proses pendidikan, dimana alokasi waktu yang digunakan 40 menit per jampelnya, satu kelas hanya terdiri dari maksimal 28 orang dari ketentuan maksimal 32 orang, jumlah rombongan 12 rombel, memberikan buku teks, dan penerapan Classroom Management. Kegiatan pembelajaran memenuhi standar poses pendidikan dengan memberikan bekal kepada semua guru keterampilan dasar mengajar serta keterampilan lanjutan mengajar. Penilaian pun menggunakan penilaian autentik yang menilai kesiapan peserta didik, proses, dan hasil belajar secara utuh. Pengawasan dilakukan dengan membuat program supervisi, melaksanakan supervisi dan membuat rencana tindak lanjut. Selain supervisi, juga diadalan coaching dan pelatihan - pelatihan terkait peningkatkan keterampilan mengajar.

Secara umum sekolah telah memiliki pembagian tugas kerja yang baik namun masih ditemukan beberapa orang yang tidak menjalankan jobdesknya. Hal ini dikarenakan dalam pengawasan masih sangat mengandalkan pimpinan sekolah, padahal seharusnya setiap orang dapat melakukan pengawasan secara mandiri atas hasil kerjanya dan menerapkan standar mutu pada pekerjaanya serta melakukan self assesment. Hal yang bisa dilakukan oleh sekolah adalah membuat sistem yang baik, dapat dipahami semua dan bisa dilaksanakan.

Sangat penting setiap sekolah memiliki tim pengembang mutu perguruan yang diturunkan kepada tim pengembang sekolah untuk mengimplementasikan kebijakan mutu yayasan. Dalam pelaksanaanya sangat diperlukan komunikasi yang baik. Komunikasi sebagai bagian dari sistem kehidupan manusia, dapat dijadikan sarana untuk mengemukakan berbagai ide atau gagasan agar personildapat memahami melaksanakan berbagai kegiatan organisasi. (Dody Hermana \& Ujang Cepi
Barlian, 2004). Hal ini sudah dilakukan oleh sekolah yang menjadi tempat penelitian. Tujuan yang utama adalah mengendalikan kualitas proses dengan perbaikan berkelanjutan sehingga dapat meningkatkan kualitas pendidikan. Pelaksanaan proses pembelajaran di sekolah ini sudah dijalankan tetapi masih berproses menuju lebih baik lagi sesuai waktu yang yang ditetapkan oleh masing-masing sekolah. Perbaikan secara berkelanjutan menjadi keharusan untuk meningkatkan kualitas pendidikan. Pembelajaran sudah sesuai kebutuhan peserta didik. Strategi, model, Metode dan teknik pembelajaran yang diterapkan pun sudah sesuai dengan tujuan pembelajaran yang diharapkan.

Berdasarkan hasil observasi dan studi dokumentasi maka monitoring dan evaluasi yang dilaksanakan untuk mengetahui dan mengontrol pelaksanaan sesuai atau tidak sesuai dengan rencana yang sudah dibuat. Monitoring dilakukan secara eksternal dan internal. Eksternal dilakukan oleh Pengawas Disdik Kabupaten, Tim pengembang Mutu/Sekolah dan Tim Pusat. Sedangkan internal dilakukan oleh Kepala Sekolah, Wakil Kepala Sekolah dan guru senior yang memiliki kompetensi yang sudah baik. Evaluasi pun dapat dilakukan dengan membuat evaluasi diri sekolah (EDS). Evaluasi diri sekolah (EDS) adalah proses evaluasi diri setiap sekolah yang bersifat internal dengan melibatkan pemangku kepentingan untuk menilai kinerja sekolah berdasarkan standar pelayanan minimal (SPM) dan Standar Nasional pendidikan (SNP) yang hasilnya dipakai sebagai dasar penyusunan Dokumen 1, Renstra, RPS dan juga RKAS. Belum semua kegiatan baik pembelajaran ataupun kesiswaan memiliki SOP. Perlu pemahaman semua elemen semua tentang pembuatan SOP. Hal ini dapat dilakukan dengan pelatihan dan pendampingan secara terprogram dan terencana. Selanjutnya SOP dapat dibuat melalui pemberdayaan unit kerja masing - masing yang kemudian dibahas dalam rapat khusus pembahasan SOP. Sekolah ini sedang berupaya menerapkan Sistem Manajemen Mutu ISO 9001:2015. Hal ini dibuktikan dengan dokumen sekolah telah melaksanakan pelatihan-pelatihan SMM ISO, telah tersedianya dokumen, secara bertahap telah mengimplementasikannya, telah melaksanakan audit internal dan tinggal menunggu Audit Eksternal untuk mendapatkan sertifikan SMM ISO 9001:2015. Pendataan hasil monitoring dan evaluasi pembelajaran masih belum optimal. Hal ini dapat diminimalisir dengan membuat pantauan program kerja yang kemudian dijadikan database dalam bentuk soft file dan print out dan disimpan dalam lemari yang tertata rapi.

Berdasarkan hasil temuan yang relevan dengan teori keilmuan dari Roda Deming ( Demings Wheel) melalui Plan (P), Do (D), Check (C) dan Action (A), sebagai berikut: (a) Plan (P). Perencanaan berdasarkan kompetensi inti, disusun matapelajaran dan alokasi waktu yang sesuai dengan karakteristik satuan pendidikan. Pada program pendidikan di 
Sekolah Menengah Pertama (SMP/MTs) dan yang setara, jumlah jam mata pelajaran sekurangkurangnya 38 jam pelajaran setiap minggu. Sedangkan pada program pendidikan Sekolah Menengah Pertama Al Azhar Syifa Budi Parahyangan, jumlah jam pelajaran menjadi 43 jam per minggu. Setiap jam pelajaran lamanya 40 menit. Jenis program pendidikan di Sekolah Menengah Pertama Al Azhar Syifa Budi Parahyangan, terdiri dari program agama yang dipecah menjadi beberapa konsentrasi ajian, mata pelajaran umum dan program mata pelajaran pilihan. Mata pelajaran yang wajib diikuti pada program umum berjumlah 10 sementara keberadaan mata pelajaran Muatan Lokal ditentukan ditentukan oleh Kemdikbud dan selanjutnya oleh kebijakan Dinas setempat dan kebutuhan Sekolah. Pengaturan beban belajar menyesuaikan dengan alokasi waktu yang telah ditentukan dalam struktur Kurikulum. Setiap satuan pendidikan dimungkinkan menambah maksimum empat jam pembelajaran per minggu secara keseluruhan. Pemanfaatan jam pembelajaran tambahan mempertimbangkan kebutuhan peserta didik dalam mencapai kompetensi, disamping memanfaatkan mata pelajaran lain yang dianggap penting namun tidak terdapat di dalam struktur Kurikulum yang tercantum di dalam Standar Isi. Dengan adanya tambahan waktu, satuan pendidikan diperkenankan mengadakan penyesuaianpenyesuaian. Misalnya mengadakan program remedial bagi peserta didik yang belum mencapai standar ketuntasan belajar minimal.

Dalam penetapan ketuntasan belajar, sekolah menetapkan kriteria ketuntasan minimal (KKM) dengan mempertimbangkan tingkat kompleksitas, daya dukung, dan tingkat kemampuan awal peserta didik (intake) dalam penyelenggaraan pembelajaran. KKM sudah dibuat cukup tinggi dimana minimal setiap mata pelajaran menentukan nilai KKM sebesar 85.Sekolah secara bertahap dan berkelanjutan menetapkan Kriteria Ketuntasan Minimal (KKM) untuk mencapai ketuntasan ideal. Perangkat pembelajaran yang meliputi pemetaan, pembuatan program tahunan, semester, silabusm RPP dan Kriteria Ketuntasan Minimal telah disiapkan diawal tahun ajaran baru. Sekolah mengagendakan program rapat koordinasi untuk menyiapkan perangkat pembelajaran ini sebelum masuk awal tahun ajaran baru dan diawal semester dua. (b)Do (D) Dalam pelaksanaan pembelajaran ini pimpinan sekolah telah mewajibkan semua gurunya untuk memiliki keterampilan dasar mengajar. Keterampilan itu diperoleh dalam pelatihan - pelatihan internal dan dalam pengembangan diri. Keterampilan tersebut meliputi kemampuan membuka pembelajaran, menutup pembelajaran, bertanya, memberikan penguatan, manajemen kelas, penyajian materi, menyiapkan media pembelajaran, memimpin diskusi kecil dan kelompok. (c)Check (C). Penilaian dan pengawasan dilaksanakan dengan tahapan pemetaan (mapping), Recovery (melalui pelatihan-pelatihan sesuai hasil pemetaan), Empowering (adanya supervise dan coaching), Improvement (peningkatan/perbaikan), Development, dan Establish. (d) Action (A). Rencana tindak lanjut (RTL) dilaksanakan dengan melihat hasil supervisi dan hasil laporan pembelajaran. RTL dibuat berupa kajian terhadap kemampuan literasi, numerasi dan social emosional. Sekolah meyakini dengan meningkatkan kemampuan tersebut akan meningkatkan kompetensi peserta didik. Untuk SDM diupgrade melalui pelatihan-pelatihan, pendampingan dan memperbanyak diskusi-diskusi melalui forum musyawarah guru mata pelajaran (MGMP). Sedangkan potensi dan kekuatan lembaga tersebut sebagai berikut: (a) Dalam mengimplementasikan proses pembelajaran terutama dalam perencanaan menunjukan peranan utama untuk menentukan program kegiatan berikutnya. (b) Pengimplementasian proses pembelajaran dalam pengorganisasian diselenggarakan dengan pengadministrasian, pengaturan, pengelolaan dan penataan yang baik sesuai dengan prinsip dan tujuan yang diharapkan. (c) Dalam hal pencapaian target pembelajaran sekolah dilakukan secara partisipatif dan kolaboratif baik internal maupun eksternal sekolah. (d) Dalam pelaksanaan proses pembelajaran senantiasa mengacu kepada target, sasaran mutu yang telah ditetapkan dan dipahami bersama. (e)Potensi dan motivasi serta komitmen kerja sebagian besar guru selalu berusaha untuk menjadi yang terbaik. (f) Perberdayaan tenaga Pendidik dan kependidikan selalu dilakukan melalui kegiatan program induksi, in house training, pendampingan, pembinaan dan kegiatan-kegiatan lainnya yang mendukung terciptanya kualitas sumber daya manusia pendidikan yang berkualitas. (g) Adanya support dari pihak yayasan melalui tim pengembang mutu menjadikan proses pembelajaran semakin baik dan lancar. (h) Perubahan peran pimpinan sekolah dari mengendalikan menjadi mengarahkan dan dari memberi menjadi memberdayakan (empowering) untuk memberikan kesempatan kepada bawahan dalam mengembangkan kreativitas serta menggali gagasan orisinil guna meningkatkan produktivitas kerja. Berdasarkan hasil riset mengenai permasalahan dan kelemahan yang timbul, peneliti dapat mengemukakan sebagai berikut (1) Quality Assurance termasuk proses pembelajaran tidak dipajang di lingkungan sekolah sebagaimana memajang visi dan misi sekolah. Hal ini dikarenakan masih ada kekhawatiran jaminan mutu yang sudah dijanjikan tidak tercapai. (2)Laporan dalam Dapodik menyatukan 4 (empat) rombongan belajar menjadi 3 (tiga) rombongan belajar (3) Adanya program Induksi, in house training, supervisi dan coaching. Tahapan yang sudah dilakukan disekolah ini adalah melakukan Mapping, Recovery, Empowering, Improvement, Depelopment dan Establih. (4) SOP program pembelajaran secara bertahap disempurnakan seiring dengan implementasi Sistem Manajemen Mutu ISO 9001 - 2015. (5) Masih belum konsisten menerapkan mana prinsip-prinsip yang 
harus dilaksanakan dan mana yang bukan terkait proses pembelajaran.

Salah satu ciri era modern dan globalisasi adalah meningkatnya persaingan, baik secara nasional ataupun internasional. Untuk dapat senantiasa berada dalam tingkat persaingan tersebut maka harus dapat memelihara, menjaga dan meningkatkan kualitas/mutu. Untuk keluar sebagai pemenang dalam persaingan tersebut khususnya dalam bidang pendidikan sangat ditentukan oleh kemampuan sekolah dalam mengelola dan meningkatkan sumber daya yang di miliki oleh sekolah sendiri terutama dalam memberikan layanan pendidikan di sekolah yang benar-benar optimal. Sekolah harus benar-benar menyadari bahwa dalam proses memenuhi Standar Pendidikan dan memenuhi harapan serta ekspektasi masyarakat, maka sekolah harus menunjukkan Value Added dalam memenuhi harapan dari masyarakat. Dengan segala potensi yang dimiliki oleh tiap sekolah seperti hasil akreditasi, raw input peserta didik, penilaian kinerja SDM, kualitas SDM yang memadai, Sarana prasarana yang baik, visi-misi dan tujuan pendidikan yang terukur dan memiliki Jaminan Kualitas /Quality Insurance maka sekolah dapat menerapkan Manajemen Mutu pembelajaran. Adapun Langkah-langkah perbaikan antara lain (1) Penerapan seven habit ke dalam proses pembelajaran untuk meningkatkan kompetensi guru untuk peningkatan mutu sekolah. (2) Adanya upaya untuk melakukan pemetaan kompetensi peserta didik dari aspek spiritual, sikap, pengetahuan, keterampilan dan fisik motoric. (3) Semua fihak harus terlibat supaya lebih memahami peran dan tanggung jawab dengan baik dan sungguh - sungguh. (4) Up grading tenaga pendidik dan kependidikan harus selalu dilakukan agar layanan pendidikan semakin berkualitas. (5) Sekolah memiliki kepercayaan diri untuk memberikan informasi Quality Assurance (jaminan kualitas) pembelajaran baik secara lisan maupun tertulis (termasuk memajang dilingkungan sekolah). (6) Dibuat instrumen monitoring/pengawasan serta dilaksanakan lebih terencana dan berkesinambungan.

\section{SIMPULAN DAN SARAN}

\section{A. Simpulan}

Berdasarkan hasil penelitian yang dilakukan maka dapat disimpulkan bahwa : 1) Sekolah telah memenuhi karakteristik pembelajaran yang menekankan kepada ranah sikap, pengetahuan dan keterampilan, perencanaan dan pelaksanaan pembelajaran terlaksana dengan baik dan tertib didukung dengan proses pengawasan yang baik oleh tim pengembang mutu, kepala sekolah, dan wakil kepala sekolah melalui program supervisi dan coaching, 2) Masalah-masalah yang dihadapi dalam analisis standar proses pendidikan SMP Al Azhar Syifa Budi Parahyangan di Bandung Raya adalahJumlah peserta didik per kelas paling banyak 28 dari maksimal 32 orang, namun pada kenyataannya pada saat pendataan di Dapodik terkait sertifikasi tetap mengharuskan jumlah siswa 32 orang. Kebijakan ini tidak sesuai dengan standar proses pendidikan ini. Belum optimalnya tenaga pendidik dan kependidikan yang baru direkrut serta SOP program pembelajaran belum optimal, dan 3) Upaya-upaya perbaikan dilakukan oleh sekolah adalah membuat laporan dalam Dapodik menyatukan 4 (empat) rombongan belajar menjadi 3 (tiga) rombongan belajar. Adanya program Induksi, in house training, program supervisi dan coaching. Tahapan yang sudah dilakukan disekolah adalah melakukan Mapping, Recovery, Empowering, Improvement, Development dan Establish. SOP program pembelajaran secara bertahap disempurnakan seiring dengan implementasi Sistem Manajemen Mutu ISO 9001 - 2015.

\section{B. Saran}

Adapun saran yang dapat disampaikan berdasarkan hasil penelitian ini, perlu adanya inovasi yang dilakukan oleh sekolah dalam pembuatan laporan dalam Dapodik menyatukan 4 (empat) rombongan belajar menjadi 3 (tiga) rombongan belajar, mengoptimalkan berbagai pelatihan untuk meningkatkan kompetensi guru dan sekolah secara bertahap menyempurnakan implementasi Sistem Manajemen Mutu ISO 9001 2015.

\section{DAFTAR RUJUKAN}

Dody Hermana \& Ujang Cepi Barlian. 2004. Komunikasi dalam organisasi. Jurnal Administrasi Pendidikan.

Edward Sallis. 2010. Manajemen Mutu Terpadu Pendidikan. Jogjakarta: IRCisoD.

E. Mulyasa. 2011. Manajemen dan Kepemimpinan Kepala Sekolah. Jakarta: PT Bumi Aksara

Gaspersz, Vincent. 2001. ISO 9001:2000 and Continual Quality Improvement.Jakarta: Gramedia.

Indra Gunawan1, Sofyan Sauri, Ganjar M Ganeswara. 2019. Jurnal Internalisasi nilai moral melalui keteladanan guru pada proses pembelajaran di ruang kelas. $n$ Association with ADSPENS.

James A.F. Stoner \& R. Edward Freeman penerjemah Wilhelmus W. Bakowatun, S.E. \& Drs. Benyamin Molan. 1992. Manajemen. Jakarta: Intermedia.

Sanusi, Achmad. 2015. Sistem Nilai. Bandung: Nuansa Cendekia

Shielilo R Amihan, PhD. 2018. Dalam an international conference on developing competencies of teachers indonesia (may 1-2, 4-5). 
Terry, G. R. 1986. Asas-Asas Manajemen. Alih Bahasa Winardi. Edisi Kedelapan. Bandung : Alumni..

Waudin Waudin, Sofyan Sauri. 2019. Implementasi manajemen peningkatan Kompetensi GuruSMA Negeri Di Kabupaten Tegal. Jurnal Kajian Manajemen Pendidikan.

Wina Sanjaya. 2001. Strategi Pembelajaran Berorientasi Standar Proses Pendidikan. Jakarta: Kencana.

Buku Penjelasan program pembelajaran Sekolah Menengah Pertama Al Azhar Syifa Budi Parahyangan. 2019
Dokumen 1. 2019. Sekolah Menengah Pertama Al Azhar Syifa Budi Parahyangan Bandung Barat.

Peraturan Pemerintah Nomor 19 Tahun 2005 tentang Standar Nasional Pendidikan

Peraturan Menteri Pendidikan No 22 tahun 2016 tentang Standar Proses Pendidikan

Undang-Undang No. 20 tahun 2003 tentang Sistem Nasional Pendidikan (SISDIKNAS) 